DOI: $10.1515 /$ pof-2015-0019

VOLUME 7, ISSUE 3, 2015

ISSN: $2036-5438$

\title{
How much Solidarity is in the EU Budget?
}

by

\author{
Mario Kölling*
}

Perspectives on Federalism, Vol. 7, issue 3, 2015 


\section{Abstract}

In this article I argue that the EU budget is (slowly) moving from a budget based on the rationale that richer EU countries help poorer EU countries in exchange for their engagement to the process of economic integration, and because economic development of the EU has positive economic returns for them, to a concept of solidarity based on a different rationale; that all member states and the Union are confronted with the same challenges and risks. In order to support this argument I analyse the development of the different budget headings as well as the increasing flexibility within the budgetary system.

Leaving aside the discussion as to whether this change is considered to be positive or negative, a reform of the own resources system and a stronger involvement of the European Parliament in the negotiation of the Multi Financial Framework would be essential to foster the trend. These reforms, together with an increase in the financial resources available, are necessary if the EU budget is to be reconciled with a solidarity role it should and has to play, in addition to giving the EU the means to properly address current and future challenges.

\section{Key-words}

EU budget, European Parliament, Multiannual Financial Framework 


\section{Introduction}

For Robert Schumann, Europe could only be forged through concrete achievements creating a de facto solidarity ${ }^{\mathrm{I}}$. However, solidarity is a complex and ambiguous concept, especially in multi-level political systems. Even among consolidated federal countries and between different levels of government there is no consensus about the required level of financial solidarity or its economic sustainability. In fact there are different expectations on the right size, expenditure priorities and optimal revenue structure of the EU budget. There is even more confusion with respect to what solidarity means in budgetary terms. The same confusion reigns with respect to how much solidarity is needed and for what purpose. Some warn about the risks of a "transfer union", whereas others believe that the only way to address current problems is to create specific permanent solidarity mechanisms, and that there is to date little sign of an "European solidarity". For some member states the budget is the true instrument for measuring the spirit of solidarity, while others underline how much solidarity has been shown so far. Following this, in the debate on the MFF 20142020, two opposing principles, "European added value", and "European solidarity", became the adopted positions of net payers and net beneficiaries. While the net payers instrumentalised the unclear concept of European added value to argue for an overall restriction of the budget, net beneficiaries appealed to the principle of European solidarity, insisting on the need of increasing European spending and subsidies. The debate on European solidarity has been especially intensive in recent years, as more and more European countries have been hit by the economic crisis.

However, EU policies are in fact primarily designed to carry out the aims of the European Union which are mainly set out in article 3 of the TUE; and these objectives include both economic aims, such as the creation of the internal market and the establishment of an economic and monetary union, and principles which have a normative foundation such as economic, social and territorial cohesion. The EU budget is expected to finance EU policies related to these aims, irrespective of their relation to economic growth, but this raises questions as to whether financial solidarity be an underlining principle for EU expenditure, and to whether solidarity mechanisms are needed in order to address specific challenges. 
In order to address these questions, I concentrate in this article on the questions of the extent and nature of solidarity already present in the EU budget. For this purpose, I analyse the size of the EU budget, the rationale of the different spending headings and the spending norms as well as the role of the European Parliament (EP) in the budgetary process and compare this analysis with four different concepts of solidarity. The argument I make is that the EU budget is (slowly) moving from a rationale based on the logic that richer EU countries help poorer EU countries in exchange for their engagement in the process of economic integration, and because net contributors realized that the development of the poorer EU economies has positive economic returns for them, to a concept of solidarity based on the assumption that all member states and the Union are confronted with the same risks. My argument is based on theoretical assumptions regarding financial solidarity based on classical principles of fiscal federalism, and a range of concepts of solidarity, as well as on an analysis of the development of the different budget headings and the characteristics of the budgetary system. Although we will concentrate in this text on the EU budget, the EU budget is not the only way for the EU to express solidarity.

\section{Some theoretical assumptions regarding financial solidarity}

The concept of solidarity is ambiguous; it may be understood as a moral value, or as an agreement of mutual assistance linking members of a community, and this ambiguity is also present in the EU Treaties (Fernandes; Rubio, 2012). Since the Schuman declaration, solidarity has been used in different legal contexts: while article 2 of the Lisbon Treaty refers to solidarity as one of the EU's values, as a principle of Community solidarity, in other parts of the Treaty there are references to "mutual solidarity" and the fair sharing of responsibilities (e.g. on external and security policies or on freedom and justice) among member states and between the Union and its member states. However, the Lisbon Treaty went deeper, and referred not only to interstate solidarity but also considered the promotion of solidarity between regions, between citizens and between generations as objectives of the EU, and moreover enshrined the 'solidarity clause' including mutual assistance among member states in specific events (e.g. if a member state is the object of a terrorist attack or the victim of a natural or man-made disaster). 
In the post-Lisbon EU I identify four different rationales that inspire solidarity, based on: (1) bargaining side payments, (2) indirect mutual benefit, (3) short term direct mutual benefit and (4) long term direct mutual benefit.

The first rationale, (bargaining side payments) means that some countries help others in exchange for their support in other decisions. Historical accounts suggest that powerful member states determine EU policy formation, and induce the cooperation of weaker members with side-payments (Moravcsik, 1998). The exchange relations are between the country benefitting directly and the contributor, but the policy fields may differ. The incentives for these side payments can be very low; they may incur high domestic political costs, and side-payments may become institutionalised in the future, but side payments can also be frequent if bargaining costs are low. If there are no secondary negotiations or bargaining chips to exchange, or opportunities for issue-linkages, there will only be weak incentives to establish these kinds of solidarity instruments. Thus, solidarity based on side payments is the outcome of bargaining and temporary situations. One example could be found in the negotiation of the Delors II package where several member states related their approval of the economic and monetary union with increasing funds for structural actions.

The second (indirect mutual benefit) means that some countries help others because this may benefit them. Political support to exercise solidarity is ensured as far as the help is conceived of as temporary or because the objectives of these policies are seen within a broader normative framework. If there is no clear temporal or normative framework, public support will vanish. The exchange relations are also established between the direct beneficiary country and the contributor and these relations are more or less institutionalised. One example could be the Cohesion Policy, where, for example, for every euro spent in Poland, on average $€ 0.46$ goes back to other member states, particularly to Germany, Austria and France, which are its top three trading partners.

The third (short term mutual benefit) is the rationale inspiring the classic insurance-type schemes. One example would be the above mentioned 'solidarity clause' (article 222 TFEU).

In this sense member states should act jointly in a spirit of solidarity if a member state is the object of a terrorist attack or the victim of a natural or man-made disaster. The need for solidarity stems from the equality of chances that member states might be confronted with the same risks. (Fernandes; Rubio, 2012) Here solidarity is conceived as a 'last resort' 
instrument, to be activated only in exceptional circumstances when a country is affected by an exogenous risk, a negative event that is not under its own control. Public support is based on the assumption that the instrument will be activated only in case of these circumstances and will not be costly in the long term. Hence, solidarity based on short term mutual benefit considerations is characterised by punctual help for specific risks.

The fourth rationale, "long term mutual benefit", may also be applied for considerations related to the establishment of mechanisms toward challenges, and in this case to the need for solidarity stems from a situation in which all member states seem to be confronted with the same risks. However the risk is not very clearly defined and may not materialise in the short term perspective. In order to address the risk all members of the community agree to invest resources with specific purposes. There may be some conditionality attached to the use of the aid (although not necessarily related to geographic criteria) based on the assumption that a coordinated action of the Union could help to prevent the risk and transform the challenge into an opportunity. The mechanism is established between all member states and the representatives of the Union, and support is based on the assumption that without coordinated action there may be negative consequences for the whole Union. Coordinated action might include an increased involvement of common institutions and procedures. There are no clear defined temporal limitations, for in this case, solidarity is not temporary and not related to specific risks; one example could be the support of the Europe 2020 Strategy for smart, sustainable, and inclusive growth.

\section{Analysis: What kind of solidarity in the EU Budget?}

\subsection{The negotiation of the budget}

Solidarity as a European concept was not explicitly the basis for the establishment of the EU budget, nor is the development of the EU budget related to arguments based on efficiency. However, in the past the EU budget has played an important role in compensating member states for anticipated losses in the integration process. Most resources have been allocated to spending programmes following quantitative arbitration among policies, rather than as a result of an assessment of the cost of each programme by reference to specific objectives. (Cipriani, 2014) This development can be seen in the evolution of the successive multiannual financial frameworks (MFF). The first MFF was 
agreed for the period 1988-1992 (Delors I package), and was negotiated in parallel with the Single European Act, where some member states linked their support for the internal market to an increase in structural funds. The final agreement included a significant increase of budgetary resources, especially structural funds, which doubled from 1988 to 1992 despite resistance from net contributors to the budget. (Wagner, 2001; Laffan, 2000; Laffan; Shackelton, 1996). According to Brennan, Spain, Greece and Portugal insisted on a doubling of the structural funds as a strict quid pro quo for agreeing to the package as a whole because their accession and the proposed reforms would lead to intensified competition for structural transfers in the poorest regions. (Brennan, 2006)

The MFF 1993-1999 (Delors II package) also contained a significant increase in structural and cohesion funds as a basis for the preparation of member states for the single currency. Moreover, the negotiations on the Delors II package took place in the aftermath of the Danish 'NO' vote on the TEU, when most member states had a strong interest in demonstrating both unity, and the capacity of the Union of reaching agreements (Kölling, 2014a). In 1999, the MFF for the period 2000-2006 secured the necessary resources to finance the eastern enlargement process of the EU. Again, several member states related their support for the eastern enlargement to specific transition periods and increasing spending in Cohesion Policy. Although the MFF 2007-2013 contained more resources and established a new and fragile link between spending programmes and policy strategy oriented towards sustainable growth and competitiveness, in line with the Lisbon Agenda, several member states demanded a freezing of the EU budget. Even though some member states tried to link the negotiation of the MFF to the debate on Treaty reform, the two debates were not carried out in parallel, and for the first time redistributive and financial negotiations were not linked to normative or constitutional debates.

The MFF 2014-2020, negotiated during the financial and economic crisis, resulted, for the first time in history, in a reduction in the overall budget. This was a clear victory for member states which are net contributors to the budget and which had taken this position from the early stages of the negotiation process. However MFF 2014-2020 reinforced the link between the budgetary headings and a policy strategy. In this sense the Europe 2020 Strategy plays an important role in the Cohesion Policy 2014-2020 and Common Agricultural Policy (CAP) 2014-2020 where spending is conditional on the fulfilment of the objectives of this strategy. 


\subsection{The size of the budget - How much money for solidarity}

The budget of a national state is generally of a considerable size, owing to the important financial consequences of many of its socio-economic policies. The combined national budgets of EU member states account on average for about $47 \%$ of total GDP enabling member states to offer welfare systems which are in general terms seen as solidarity instruments. The EU budget stands at about 1\% of the EU GDP. However, the size of the budget may not always give insights on the level of solidarity, since $94 \%$ of the EU budget is spent in the EU countries on policies and programmes that benefit citizens directly. Moreover, an examination of the size of the EU budget shows that there is a clear tendency, at least until 2014, of increasing resources (see Figure I). As already mentioned, the sharp increase in size of the EU budget in the late 1980s and in the 1990s were caused by the two Delors packages that reformed the budget and significantly increased the amount of structural funds allocated within the Union. The reforms of the Cohesion Policy were part of a much larger reform of the European Community which culminated in the Single European Act in 1992.

Figure I:

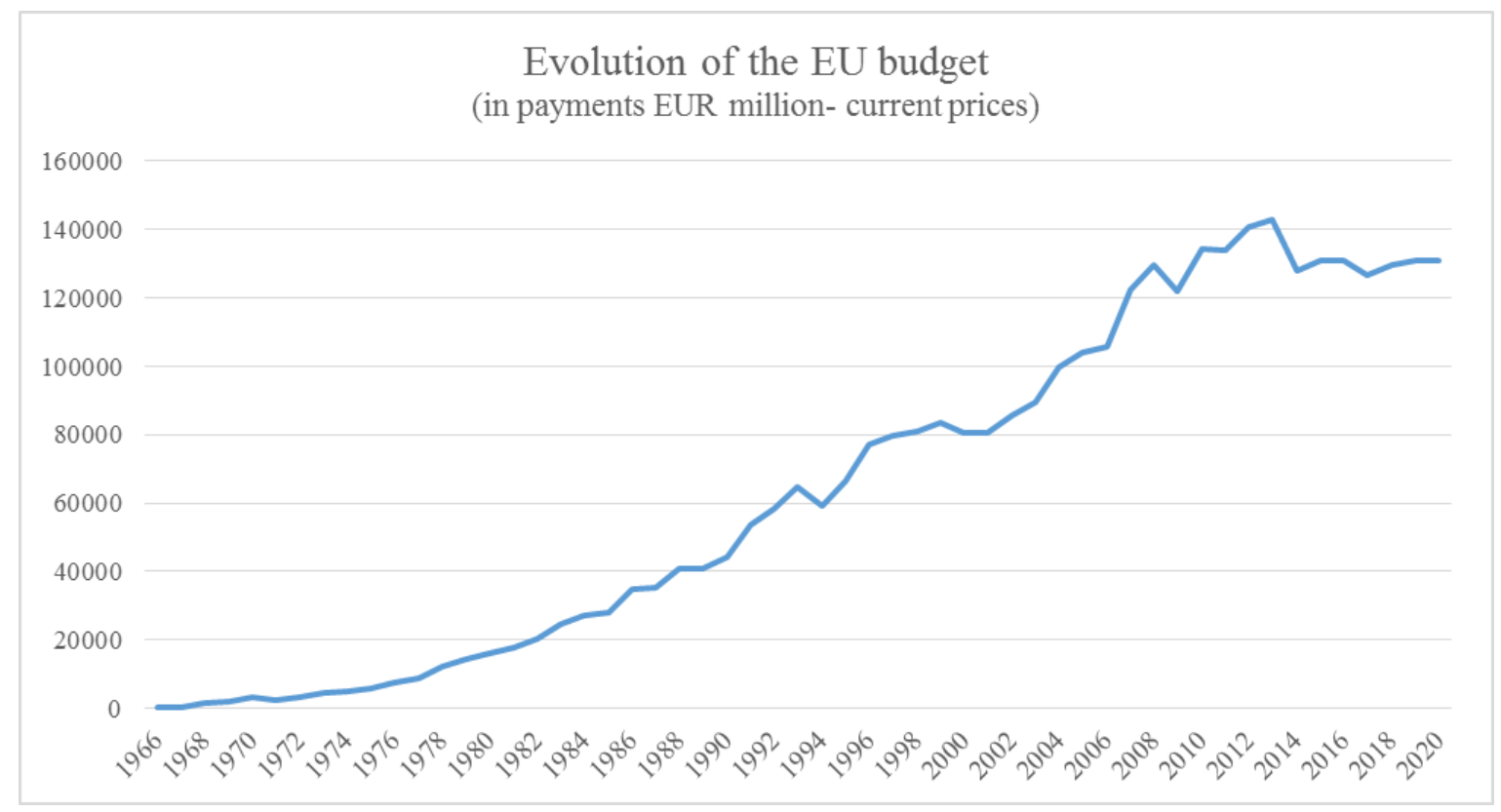

Source: Own elaboration 
In the context of budgetary constraints at the national level during the financial and economic crisis starting in 2007, the MFF for the period 2014-2020 was reduced for the first time in its history. The overall level for commitments has been set at $€ 960.000$ million for 2014-2020 which remains 1\% of the EU GDP but represents $€ 15.000$ million less than in the period 2007-2013. However, until 2013 we had seen a trend in which annual budgets have been lower than the ceiling established through the MFF. Moreover, there have also been 'quantitative' ceilings, with member states agreeing an overall limit to the resources for the EU budget and a limit for financial aid that a country can receive. In this sense solidarity (meaning the resources which a country can receive from the EU budget) has been fixed first (2004) at 4\% and later set at between 3.23\% and 3.78\% of national GDP. Together with other restrictions, the absorption limits had led to the situation where not all budgetary resources could be spent, and had to be returned to the national budgets. However, after 2015, unspent money can be carried over from one year to another and the Commission can adjust the payment ceilings using unspent money from the previous year. In this sense, although the overall ceiling has been reduced, the allocated resources will be available for the whole spending period. (Kölling, Serrano 2013)

\subsection{The budget headings}

The difference in size between the EU's budget and those of the member states explains why broad social redistribution cannot be a principal task of the Union. Moreover the EU has no great capacity to promote macroeconomic stability through its budget- a role routinely undertaken by the highest level of government in other systems. During the debate on measures designed to combat the crisis, it was striking that there was virtually no discussion of whether or how the EU budget could be used for this purpose. While social redistribution and its effectiveness on the economic crisis has been uneven among member states, there are scenarios that affect all member states in a similar way.

In fact, analysing the different budget headings we can see a shift from traditional spending towards spending on policy goals. Since 2007, R\&D and competitiveness have become a key priority (see figure II, III and IV). This trend has been reinforced since 2010 with the adaptation of the Europe 2020 Strategy, in which the EU set out its aims to "promote a more resource efficient, greener and more competitive economy" and to become the most competitive region in the world. 
Figure II: Distribution of spending headings $2000-2006^{\mathrm{II}}$

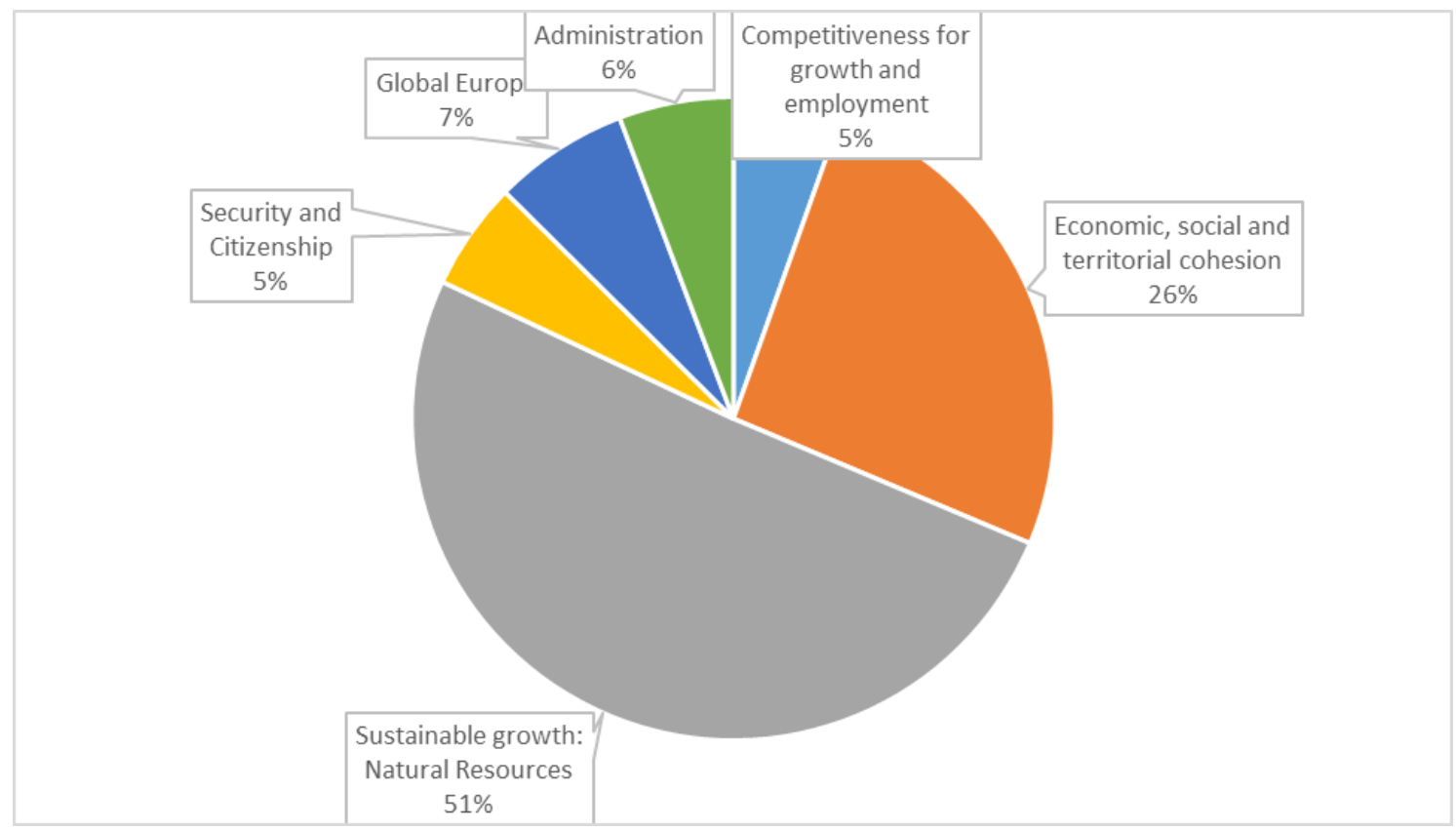

Source: Own elaboration, European Commission (2009), EU budget 2008, Final report, Luxembourg: publications office of the European Union.

Figure III: Distribution of spending headings 2007 - 2013

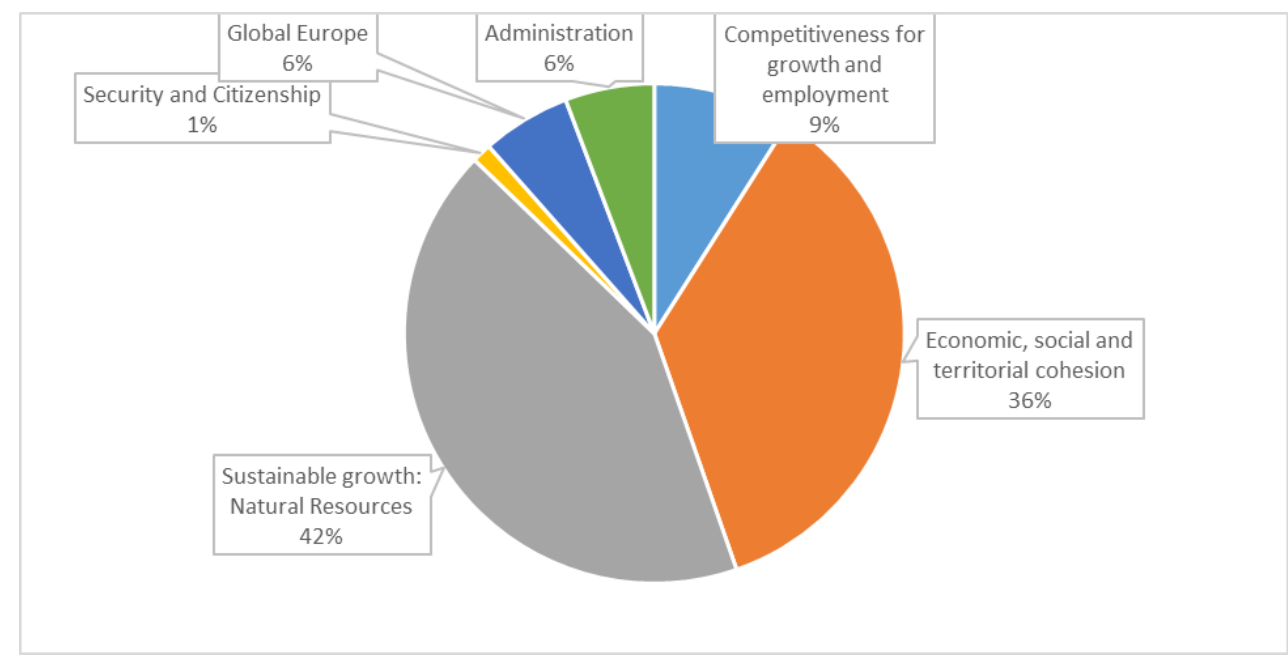

Source: Own elaboration, European Commission (2009), EU budget 2008, Final report, Luxembourg: publications office of the European Union. 
Figure IV: Distribution of spending headings 2014 - 2020

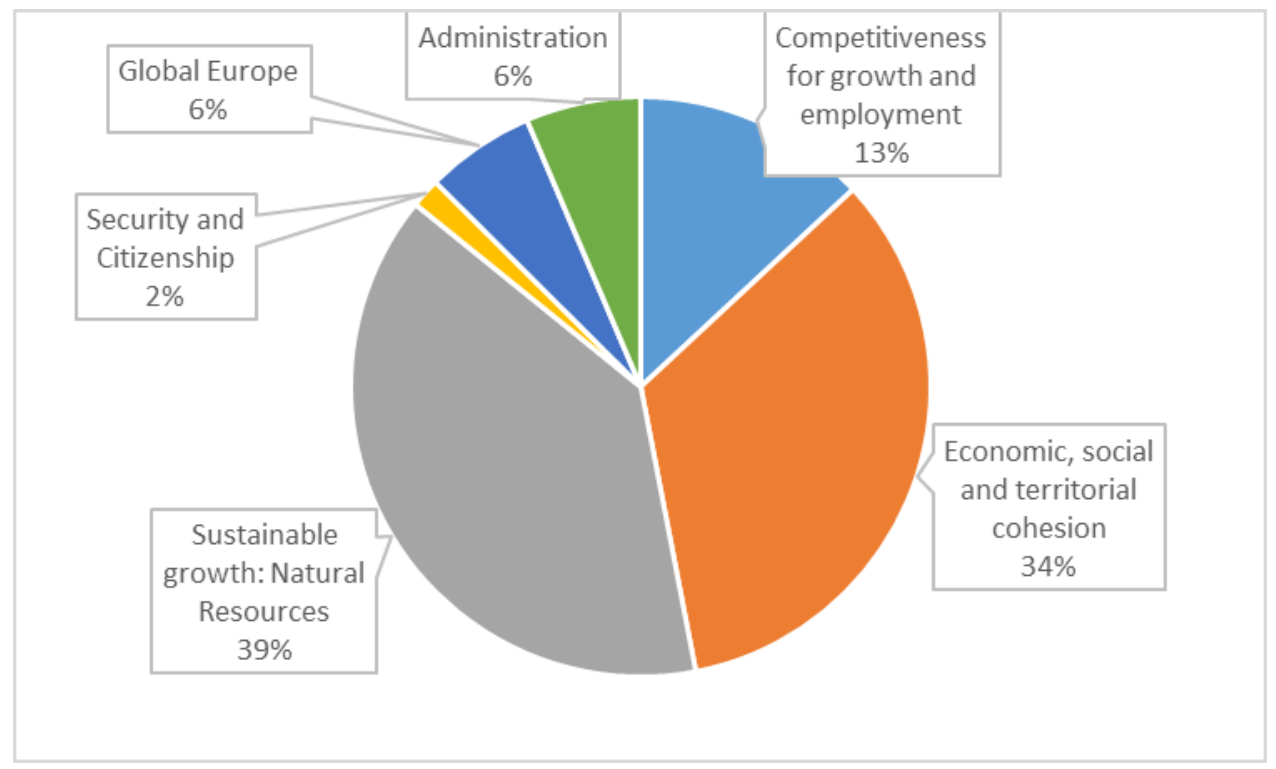

Source: Own elaboration

Figure V: Comparing of the spending headings between the MFF 2007-2013 and the MFF 2014-2020.

\begin{tabular}{lccc}
\hline $\begin{array}{c}\text { (EUR million } \\
\text { - 2011 prices) }\end{array}$ & $\begin{array}{c}\text { MFF } \\
\text { 2007-2013 }\end{array}$ & $\begin{array}{c}\text { MFF } \\
\text { 2014-2020 }\end{array}$ & $\begin{array}{c}\text { Variation MFF 2014-2020 } \\
\text { to MFF 2007-2013 }\end{array}$ \\
\hline $\begin{array}{l}\text { 1a. } \\
\text { Competitiveness } \\
\text { for growth and }\end{array}$ & 91.495 & 125.614 & $+34.1(+37,3 \%)$ \\
employment & & & \\
$\quad$ 1b. Economic, & 354.815 & 325.149 & $-29.7(-8,4 \%)$ \\
social and & & & \\
territorial \\
cohesion \\
2. Sustainable \\
growth: Natural
\end{tabular}


market related

expenditure and

direct payments

\begin{tabular}{cccl}
$\begin{array}{c}\text { 3. Security } \\
\text { and Citizenship }\end{array}$ & 12.366 & 15.686 & +3.3 \\
alobal & 56.815 & 58.704 & $(+26.8 \%)$ \\
$\mathbf{4}$ & & & +1.9 \\
Europe & & & $(+3.3 \%)$ \\
5. & 57.082 & 61.629 & $+4.5(+8 \%)$ \\
Administration & & & \\
\hline
\end{tabular}

Source: Own elaboration

An analysis of the different budget headings confirms the shift from traditional spending on the CAP and Cohesion funds towards spending on specific policy goals. While during the nineties the EU targeted over $80 \%$ of its budget in favour of structurally weak, and agricultural members, this percentage has been reduced. As already mentioned this is not only due to budgetary constraints but also because of the growing importance of policy strategies, and their interlinkage with the EU budget. According to this trend, in the MFF 2014-2020 the two main spending headings have been renamed in accordance with the main strategies in Europe 2020. Indeed, besides semantic enhancements, spending programmes under sub-heading 1a ("Competitiveness for growth and jobs") contribute to the fulfilment of the Europe 2020 Strategy, in particular as regards to the promotion of research, innovation and technological development, as well as specific actions in favour of the competitiveness of enterprises and SMEs. In the MFF 2014-2020 this spending block sees its funding go up by $37 \%$ to $€ 125.700$ million compared to the former MFF (see Figure III). In this sense programmes are oriented towards increasing the competitiveness of the EU as a whole within a global market; among the strategic goals of this programme is the challenge facing the EU in increasing the Union's position in international innovation scores (Kölling, 2014b).

On the other hand, spending programmes on traditional headings, e.g. sub-heading $1 \mathrm{~b}$ ("Economic, social and territorial cohesion"), have been reduced. Cohesion Policy had been traditionally one of the largest budget items, which had been considered as the main tool of solidarity through its support of the socio-economic development of the poorer 
member states and territories and to a certain extent as a weak equalization arrangement; however there are important differences to federal equalization programmes, both in philosophical and economic terms. According to the Lisbon Treaty, the EU "[...] shall promote economic, social and territorial cohesion, and solidarity among member states." Article 3 TUE therefore implies that Cohesion Policy is aimed at providing solidarity between the member states and regions, and particularly at helping the poorer member states and regions "catch up" economically with the EU average. Cohesion is made evident in various ways but notably through significant transfers from the EU budget, where resources are redirected to peripheral and economically weaker regions, not in order to reshuffle assets in the short-range perspective, but to upgrade their enduring productive capabilities. However, under the Commission's list of territories benefiting from territorial cohesion, almost all types of geographic and socio-economic areas are covered: urban, rural, coastal and fishing areas; regions suffering from natural disadvantages or serious, chronic demographic issues.

Cohesion policy has always been tied to implementation rules, creating a dynamic equilibrium between solidarity and responsibility. It has had a long history in which it has been shown to be capable of adapting its objectives and delivery structure to new challenges, mainly because criteria for eligibility for existing funds and the equilibrium between solidarity and responsibility have been adapted during the past decades. In budgetary terms Cohesion Policy has helped to achieve a significant level of solidarity. However, as already mentioned, the Cohesion Policy 2014-2020 also contributes to the objectives of the Europe 2020 Strategy. In this sense, and in addition to the objective of structural development, the European Regional Development Fund and the Cohesion Fund have to pursue the goals of economic growth and jobs creation.

Moreover there are new and stricter conditions for implementation. While macroeconomic conditions, which combine penalties and enforced aid, will ensure that the rules of economic governance are followed; "ex ante" conditions have to make sure that the conditions necessary for effective support are given.

The origin of the Common Agricultural Policy - ("Sustainable growth: Natural Resources") - dates back to the Treaty of Rome and could be considered the unique distributive policy of the EU. European solidarity in terms of farming was initially expressed in the financing of the CAP. In 1958, the Declaration of Stresa defined its basis: 
"In the name of financial solidarity, all the member countries of the EEC take part in the financing of the burdens of the Community such as guaranteed prices for farmers, the export of surpluses or even the policy of aid and improvement of structures. All the costs engendered by the CAP must be borne in common." (Chambon, 2012) Distributive policies involve allocations of financial resources and benefit, not from one side to another but rather from the contributors to selected beneficiaries. There is also an element of redistribution in the common agricultural policy, where the second pillar of the CAP should ensure development of rural areas. Although the achievements in these fields are far from negligible, the redistributive impact is nevertheless commensurate with the modest volume of the budget for rural development. Distributive policies are also often "patronage" policies which are characterised by close political ties between the bureaucracy and strong sector specific interests. In this sense where the distribution of direct aid is more advantageous to big farming countries, it is to the detriment of countries with little agriculture; moreover the distribution of direct aid is less advantageous for new member states and for countries with different territorial specialisation.

Although market related expenditure and direct payments remain the main spending categories of the budget there have been some important reforms made. With regard to MFF 2014-2020 firstly, spending on heading 2 has been reduced by $11 \%$. Secondly the CAP has also been integrated into the Europe 2020 Strategy objectives. In this sense a strong emphasis has now been put on expenditure aimed at boosting growth and creating jobs. The change in the orientation of the CAP can be seen in the evolution of expenditure, reflecting the policy shift since 1992, away from product based support towards producer support and considerations for the environment.

Actions under the heading "Security and Citizenship" constitute a diversified range of programmes related to asylum and migration and initiatives in the areas of external borders and internal security, as well as measures in the field of justice. With regard to the current MFF, there are significant changes in the headings compared to the 2007-2013 period. Starting from a low level the budget allocation for 'Security and citizenship' has grown by around $27 \%$. Many aspects of asylum and migration policy, including external borders and internal security, are based on long term common risk perceptions, which affect all member states of the Union. 
The same trend can be confirmed for the heading "Global Europe", which supports solidarity actions beyond EU borders, in particular by delivering urgent humanitarian assistance and development aid. During MFF 2014-2020 the envelope for the development cooperation instrument was of $€ 17.300$ million, the neighbourhood policy $€ 13.600$ million, and the pre-accession instrument, $€ 10.500$ million. This represents an improvement with regard to the former MFF (Kölling; Fernandez, 2012). The programmes of heading 4 can be considered to be similar to the spending on headings 3 in that they are motivated by the rationale of common risks prevention. Although member states have geographic preferences, neighbourhood policy, development cooperation and the creation of the European External Action Service can be considered to be in the common European interest. Within this category we could also name the European Development Fund ${ }^{\text {III }}$ which provides aid for development cooperation with African, Caribbean and Pacific countries, as well as overseas countries and territories.

\subsection{The spending rules - less autonomy more solidarity}

\subsubsection{Solidarity and flexibility}

As already mentioned increasing flexibility of the budget has resulted in less control by the member states and has increased the discretionality of budgetary actors. Within the current MFF we can confirm an increased flexibility within the budget both related to the temporal dimension but also among budgetary headings.

- The mid-term adjustment of the national allocations under the "Investment for growth and jobs" goal of the Cohesion Policy (thus applicable to the period 20172020) will be carried out on the basis of up-dated GDP statistics in 2016.

- The agreement includes a contingency margin aimed at allowing flexibility within the MFF 2014-2020 to cope with unforeseen circumstances.

- As regards to the CAP, the MFF maintains its relevance while, at the same time, introduces elements of reform in an effort to modernize this common policy. Allowing for greater flexibility in the use of the rural development funds is a step forward in narrowing the "technologic gap" between different regions, and addressing the specificities of different countries. 
- Regarding flexibility the final compromise between the EP and the Council includes a formula for calculating the sums that can be carried over from one year to another, after 2015 the Commission will adjust the payment ceilings using unspent money from the previous year, but with a cap of $€ 7$ billion for 2018 , $€ 9$ billion for 2019 and $€ 10$ billion for 2020 .

\subsubsection{Conditionality and spending priorities}

The EU budgetary instruments are grants and loans which are increasingly characterised by a low level of discretion given to beneficiary member states, mainly due to higher control mechanisms but also due to increasing conditionality, where the precise conditions and restrictions have been changing and growing. In this sense more solidarity means less autonomy, and the MFF 2014-2020 especially makes clear that the relationship between solidarity and normative commitment has changed, and that other, more political factors, are at work in the implementation of the policy.

The new macroeconomic conditionality aims to link the allocation of structural funds to good economic governance, is applied to all funds and may result in a suspension of part or all payments. However macro-conditionality does not mean that a member state would see its aid automatically suspended for an excessive budget deficit procedure. Nevertheless this could be the case if the government of a member states does not react to a request from the Commission to adjust its programmes. ${ }^{\text {IV }}$ With regard to the CAP we can also find increasing conditionality related to more targeted cross-compliance, in which the compulsory basic layer of environmental requirements and obligations to be met in order to receive full CAP funding are represented.

\subsection{The growing role of the EP - the representative of the common interest}

The EU's budget has been traditionally negotiated between member states which considered the specific budgetary headings as acquired 'budgetary rights'; these were framed by the unanimity rule, which fostered resistance to the reform of the budget. However, the European Parliament has assumed a new role in the negotiation of the MFF 2014-2020, where the Lisbon Treaty gave the EP a new formal role in the adoption of the regulation which sets up the MFF. The EP has the right of consent over the spending side of the budget where a majority of MEPs can approve or reject the agreement reached by 
the European Council, although formally it cannot negotiate it. But the EP has not only a new formal role in the final phase, as it has already been one of the major players from the very beginning of the current negotiation process:

- the EP did not wait for the Commission's proposal before presenting their own position and adopting a Resolution on the MFF,

- the EP elaborates position papers on conflictive issues according to the negotiation steps of the Council, and

- the EP representatives meet the Trio Presidency ahead of the Council of General Affairs.

Conscious of this new role, the EP highlighted on several occasions during the negotiation process that the budget proposal debated by EU leaders did not reflect the priorities and concerns of the Parliament which were much more concentrated on, and oriented towards, common EU goals. The new informal procedure enabled the MFF 20142020 to be "negotiated" between the Council and the EP. Alain Lamassoure, the European Parliament's chief MFF negotiator commented that "It is only since the Lisbon Treaty that the European Parliament has fully deserved to be called a parliament. It now has all the budget powers a parliament in a federal system has. It is the first time that these new powers can be exercised on a multiannual financial framework." " The new role of the EP enabled the "politicisation" of the discussion on the MFF and the introduction of budgetary goals related to both the expenditure and the revenue side which represent the common interest of the whole Union.

\section{Conclusions}

At the beginning of the integration process financial solidarity as a particular guiding principle was not part of the considerations of member states. Later on the budget was, rather, rooted in the national calculation of implementing self-interests, and it is only during recent years that the budget has become an instrument to support policy programmes related to addressing common challenges.

Nevertheless the concept of solidarity remains ambiguous, and has been used in different contexts: as one of the EU's values, as a principle of Community actions, but also as "mutual solidarity" and related to the fair sharing of responsibility. Furthermore 
solidarity refers to the relations among member states, between the Union and member states, but also between regions, between citizens and between generations, as objectives of the EU.

Consequently, I have been able to identify four different rationales inspiring solidarity in the EU, which have specific focus and purpose in solidarity arrangements, and different natures and motivations, levels of institutionalisation; time frames and promotors.

In this article I have argued that the EU budget is (slowly) moving from a rationale that richer EU countries help poorer EU countries in exchange for their support for the process of economic integration and because economic development of the EU has positive economic returns for them, to a concept of solidarity based on the assumption that all member states and the Union are confronted with the same challenges and risks. In other words the budget is changing from being an instrument to accommodating member states preferences to a policy instrument.

The analysis of the development of the negotiation of the MFF, the budget headings, and spending rules, as well as the role of "new" budgetary actors confirms this argument.

It may be hard to detect elements of solidarity in the budget, especially if we consider the development and/or the role of the EU budget in the current economic crisis. However, we have to specify the means and rationale of solidarity and differentiate between long and short term solidarity. Since the beginning of the integration process solidarity arrangements have been driven by bargaining and side payments e.g. the creation of the CAP and Cohesion Policy. Moreover the shift in the EU revenue system from own resources to member states' contribution (based on national GNI) has reinforced the trend that richer EU countries help the most distressed ones; both because net contributors would also benefit from the measures, and because beneficiaries interrelated re-distributive polices to further integration steps.

However there is also a growing understanding that the EU is facing an increasing number of challenges which affect all member states. This new perception has underlined the shift from traditional spending towards spending on targeted policy objectives. Growing numbers of instruments are based on the rationale of short and long term mutual benefit.

With regard to short term direct reciprocity, there is a growing number of EU operations in the wake of disasters and major accidents, which are undertaken in the 
interest of the victims. For this purpose there have been specific instruments created (e.g. the Emergency Aid Reserve; the European Globalisation Fund; the Solidarity Fund and the Flexibility Instrument). EU countries commit themselves to reciprocal aid instruments in face of a risk that is equally spread among member states. All EU countries are thus potential givers and receivers of help. Alongside the increasing resources for these instruments, also comes an increased scope for intervention, and, taking into account past experience, more flexible mechanisms enable the $\mathrm{EU}$ to mobilise funds to react to unforeseen events such as a crisis and emergency situations.

The structure of the MFF 2014-2020 differs from the Delors I package; the structure of the spending headings confirms the decreasing importance of the traditional spending headings (Cohesion Policy and CAP) and the increase of competitiveness and job creation expenditures. Whilst evidently the EU budget is too small to be a useful instrument, it is generating a long lasting impact.

One of the main questions and challenges of the Union could be to make this solidarity visible. Citizens do not know how the budget is spent. In this sense, there is a clear need for more transparency and an increasingly clear visibility of European solidarity in the form of EU programmes. The visibility of EU's spending and revenue could well be the catalyst for an unprecedented debate about the EU budget, and ultimately about Europe as such. The shifting of the liability for funding the EU budget from member states directly to citizens might especially foster the role of the European Parliament and enable autonomous decision at EU level on the volume of the resources for the EU budget and the level of European solidarity.

\footnotetext{
* Senior Researcher, Fundación Manuel Giménez Abad, Zaragoza. Mario Kölling’s contribution is part of the research developed in the context of the project 'Costes y beneficios de la descentralización política en un contexto de crisis: el caso español’ (MEC, DER2012-39179).

I Schuman Declaration, 9 May 1950

II This table provides the distribution of the spending period 2000-2006 based on the headings of MFF 20072013 in order to provide an overview of the evolution of EU policies. There have been mayor changes in the $\mathrm{EU}$, mainly in relation to the number of member states.

III As it is not funded from the EU budget but from direct contributions from EU Member States, the EDF does not fall under the MFF.

IV The Commission may request a Member State to review and propose amendments to its Partnership Contract and the relevant programmes, where this is necessary to support the implementation of:

(a) recommendations under the broad guidelines of the economic policy;

(b) employment recommendations;

(c) specific measures addressed to euro area Member States in accordance with Article 136(1);

(d) recommendations under the excessive deficit procedure;

(e) recommendations under the excessive imbalances procedure;
} 
(f) union support under the medium-term balance of payments facility;

(g) union support under the European financial stabilisation mechanism;

(h) financial assistance under the European Stability Mechanism.

V "If we abdicate our powers, we no longer deserve our name" - Interview with Alain Lamassoure, European

Parliament's chief MFF negotiator, EUROPOLITICS, 01 March 2013.

References

- Ackrill Robert, 2003, 'Stabilization in EMU: A Critical Review', in Baimbridge Mark and Whyman Philip (eds), Fiscal Federalism and European Economic Integration, Routledge: London \& New York, 103-118

- $\quad$ Becker Peter, 2012, Lost in Stagnation - The EU's Next Multiannual Financial Framework (2014-2020) and the Power of the Status Quo, SWP Research Paper 14, Stiftung Wissenschaft und Politik, Berlin.

- Begg Iain, 2012, Using the EU budget to achieve macroeconomic stabilisation, Friedrich-Ebert-Stiftung, Internationale Politikanalyse.

- $\quad$ Benedetto Giacomo and Milio Simona (eds), 2012): European Union Budget Reform: Institutions, policy and economic crisis, Palgrave, Basingstoke.

- Brennan Peter. 2006, Negotiating the Delors 1 Package. Making a Success of the Single Act, Unpublished Working Paper.

- Chambon Nadège, 2012, Is the CAP a ground for European disunion? An assessment of the solidarity mechanisms created by the CAP and their relevance after 2013, Notre Europe, policy paper 45.

- Cattoir Philippe, 2009, Options for an EU financing reform, policy paper 38, Notre Europe.

- Cipriani Gabriele, 2014, Financing the EU Budget: Moving forward or backwards?, Economic Policy, CEPS Paperbacks, Brussels.

- $\quad$ European Commission, 2011, A Budget for Europe 2020, COM (2011) 500 final.

- $\quad$ European Commission, 2010, Europe 2020 Flagship Initiative - Innovation Union, COM (2010) 546 final, Brussels.

- Feld Lars P. and Necker Sarah, 2010, Fiskalföderalismus in der Europäischen Union: Herausforderungen für die Reform der Finanzverfassung der EU, European Liberal Forum, Brüssel.

- Fernandes Sofia and Rubio Eulalia, 2012, Solidarity within the Eurozone: how much, what for, for how long?, Notre Europe, policy paper 51.

- $\quad$ Figueira Filipa, 2008, A Better Budget for Europe: Economically Efficient, Politically Realistic, Swedish Institute for European Policy Studies, European Policy Analysis 2.

- Haug Jutta, Lamassoure Alain and Verhofstadt Guy, 2011, Europe for growth for a radical change in financing the EU, report, Notre Europe - CEPS, 06 April 2011.

- Heinemann Friedrich, Mohl Philipp and Osterloh Steffen, 2010, 'Reforming the EU Budget: Reconciling Needs with Political-Economic Constraints', Journal of European Integration, XXXII(1).

- Kölling Mario, 2014a, Preferencias e instituciones: un análisis comparativo de las negociaciones del Marco Financiero Plurianual de la UE, Centro de Estudios Políticos y Constitucionales, Madrid

- Kölling Mario, 2014b, 'The Multiannual Financial Framework 2014-2020 and the Europe 2020 Strategy - Ambitions beyond (financial) Capacities? Path dependency and the EU Budget', Czech Journal of Political Science; $2 / 2014$.

- Kölling Mario and Fernández Sola Natividad, 2012, "The EU external actions in the next EU multiannual financial framework (2014-2020) - closing the gap between ambitions; expectations and capability', Real Instituto Elcano; Working paper 16/2012.

- Kölling Mario and Serrano Leal Cristina, 2013, 'Towards an Agreement on Growth and Job Creation? The Multiannual Financial Framework 2014-20 on the Agenda of the European Council of 7-8 February 2013', Real Instituto Elcano; ARI 4/2013 - 4/2/2013.

- Laffan Brigid, 1997, The finances of the European Union, Macmillan, London.

- Laffan Brigid, 2000, 'The Big Budgetary Bargains: From Negotiation to Authority', Journal of European Public Policy, VII(5): 725-743. 
- Laffan Brigid and Shackelton Michael, 1996, 'The Budget', in Wallace, Helen and Wallace, William (eds), Policy-making in the European Union, Oxford University Press, Oxford, 71-96.

- Lamassoure Alain, 2011, 'The financial crisis: what kind of recovery is possible? An outlook on the European budget: from financial solidarity to budgetary solidarity?', in Schuman Report on Europe: State of the Union 2011, Springer, New York and Heidelberg.

- Lamassoure Alain, 2012, 'The Budget: For a European Solidarity Pact', in Schuman Report on Europe 2012, Springer, New York and Heidelberg.

- Mattila Mikko, 2006, 'Fiscal Transfers and Redistribution in the European Union: Do Smaller Member States Get More than their Share?', Journal of European Public Policy, XIII(1): 34-51.

- $\quad$ Mayhew Alan, 2012, Reforming the EU budget to support economic growth, SEI Working Paper, no. 128.

- Moravcsik Andrew, 1998, The Choice for Europe: Social Purposes and State Power from Messina to Maastricht, Cornell University Press, Ithaca, NY.

- Núñez Ferrer Jorge et al., 2012, The Use of Innovative Financial Instruments for Financing EU Policies and Objectives: Implications for EU and National Budgets, Economic Policy, CEPS Special Reports, NO. 68/10/2012.

- Padoa-Schioppa Antonio, 2013, 'Guidelines for a Constitutional Reform of the European Union', Perspectives on Federalism, V(1): I-XVI.

- Schneider Christina J., 2011, 'Weak States and Institutionalized Bargaining Power in International Organizations', International Studies Quarterly, LV(2): 331-355.

- Tarschys Daniel, 2011, 'European Public Goods: Which Selection Criteria for the Multiannual Financial Framework?', in Tarschys Daniel (ed), The EU Budget: What Should Go In? What Should Go Out?, report 3, Swedish Institute for European Policy Studies, Stockholm.

- Wagner Wolfgang, 2001, 'German Foreign Policy Since Unification. Theories Meet Reality', in Rittberger Volker (ed), German Foreign Policy Since Unification. Theories and Case Studies, Manchester University Press, Manchester, 296-322. 